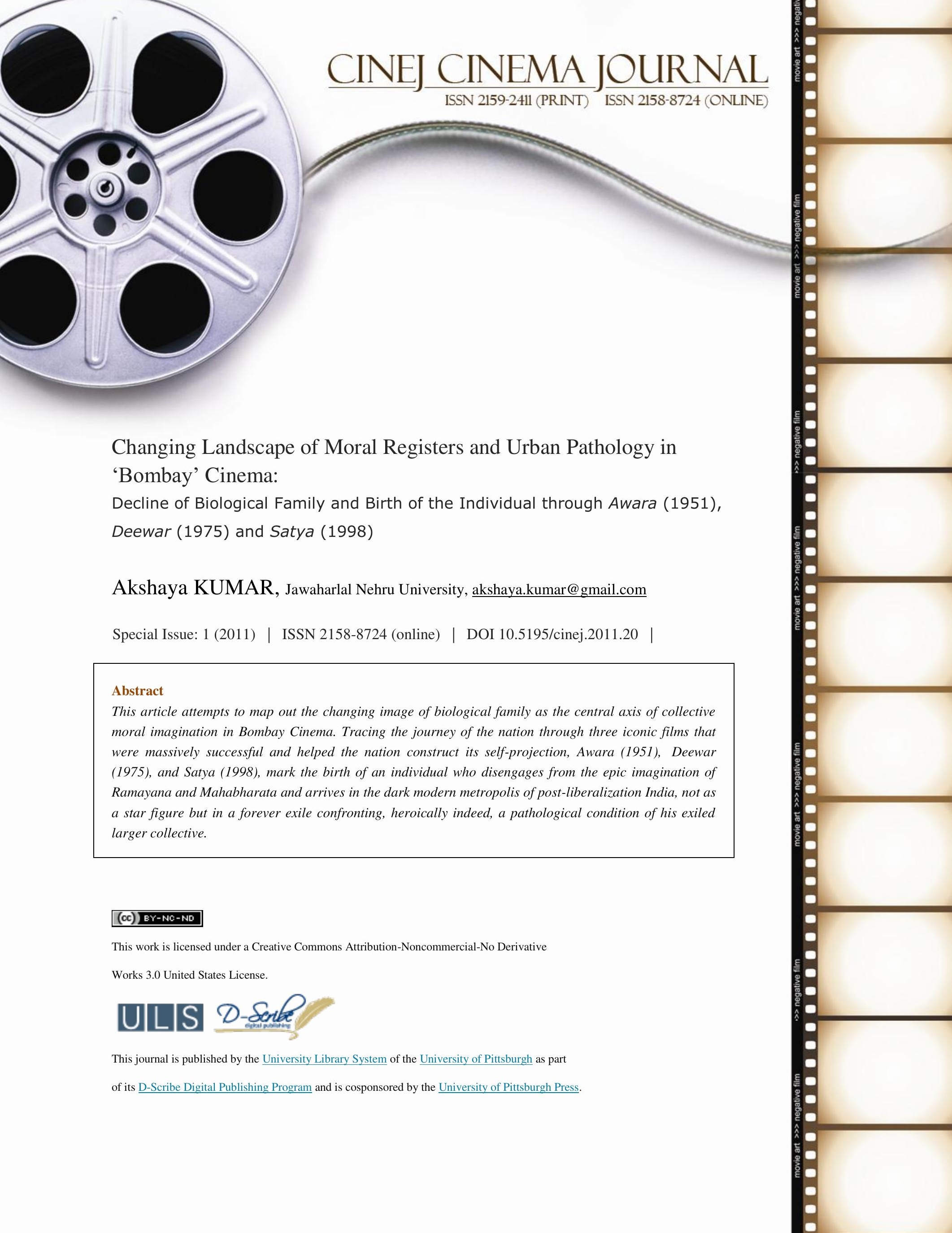




\section{Changing Landscape of Moral Registers and Urban Pathology in 'Bombay' Cinema: Decline of Biological Family and Birth of the Individual through Awara (1951), Deewar (1975) and Satya (1998)}

Vijay: Aj mere paas buildigein hain, property hai, bank-balance hai, bangla hai, gaadi hai, kya hai tumhare paas? [Today, I've got buildings, property, bank-balance, bungalow, car, what've you got?]

Ravi: Mere paas maan hai! [I have my mother!]

(Deewar, 1975)

\section{Introduction}

The figure of the mother in Indian Cinema has traditionally contained far too many meanings - the familial being the least important. The ideology of the Hindi film leans too heavily on the mother figure. The moral justification of the trajectory protagonist(s) follows is either mounted on her or sought out of her. She is rendered a timeless moral appeal for she submits to all excesses inflicted upon her in order to derive moral strength from them. The mother's position, then, becomes the canvas over which the protagonist's narrative trajectory is painted; she becomes the moral axis of the entire landscape of the story. While the protagonist of the film may question the morality of all social systems around him, he'd have to return to the mother to redeem himself off his own moral culpability.

However, the figure of the mother often becomes an abstraction for the family, which is used as a counterpoint to society in order to mark the distinction between private and public, selfish interest and community interest. This paper tries to look at the shifting articulation of the moral culpability of Bombay, the metropolis, which also happens to be the center of Bombay cinema, often termed Hindi cinema or the Indian cinema. To trace the journey of this fundamental conflict between family and society, we must begin with the Nehruvian moment and contrast it with the 1970s when the disappointment with the state took to streets and the dream of a free and just society eventually came apart. Our next leap shall be to the post-globalization era when the city of Bombay witnessed widespread mafia activity after the closing down of Textile mills and therefore, rapid rise in the number of unemployed youth - migrants or otherwise. The Gangster cinema, then, staged the subaltern excesses in alternate spaces from within Bombay. Prasad writes,

After the 50s, the popular cinema by and large maintained a loyalty to this consensual valuation in its narratives, until the $70 \mathrm{~s}$ when with the rupturing of the national consensus, the city suddenly re-entered the screen as a self-sufficient space for the staging of epic conflicts and allegorical narratives, with the village figuring increasingly as no more than a memory fragment, a psychic residue, or as an outsider element that threw the otherwise overpowering presence of urban life into some sort of perspective. (Prasad, 2004: 98)

In order to study the above mentioned trajectory in detail, I've chosen three iconic films representing their respective moments: Awara (1951), Deewar (1975) and Satya (1998). All these films not only mark the moment they are born out of but also made a huge impact on the films to follow them. While the family moves 
from being a counterpoint for society in the 1950s to the vehicle of a traumatic memory that the individual rebels against in the 1970s, the individual that rose as a star in the 70s must be re-born eventually in the 1990s without the burden of memory, as a non-star, as an ordinary human being who would not be the carrier of an epic tale, but tell his own story. This birth of a non-star individual was indeed a major shift in the scale of cinematic tales as the grand narrative. The epic scale disappears along with the deeply moral question and the star figure who could have carried it. Let us begin our investigation of the shifting trends by looking at how the star-text unfolds itself within the city space.

\section{City and Stardom: Vehicles for Grand Narratives \& Epic Battles}

Both Awara and Deewar are born out of the Nehruvian dream. The former endorses the Nuhruvian moment and the latter erupts from the failure of that dream. Nehru, then, must be considered the ultimate star figure of the post-independence era during which he publicly encouraged and supported the stars, attended awardgiving ceremonies and patronizing the industry. Hiren Mukherjee writes,

Nehru's idealistic optimism and woolly romanticism, his almost detached, dream-like approach to politics, laid the foundations for the ethos prevailing in the first decade after Independence. The euphoria induced talk of sacrifice and noble ideals. Nehru was something of a cult figure himself, a super-star among stars. (Mukerjee, 1964)

Nehru's speeches inspired popular imagination in the 50s. He was the man of big nationalist projects like the big dams, which he called the temples of modern India, and five-year plans. Early Raj Kapoor films like Awara, and later Shri 420, endorsed this dream. However, Raj Kapoor built his star persona - the public image of the actor as a concrete person that is inferred from his or her screen presence and associated publicity (Miller, 2000: 595) - as a tramp (based on Chaplin) as opposed to Nehru's sophisticated appeal. As a street urchin, he defies "the 'predatory identity' of the city to paradoxically navigate the city more efficiently, perhaps even creatively" (Nandy, 2001: 26). While he pushed forward Nehru's imagination, he mounted it on his own unique star-text which placed him on the fringes of urban spaces but from where he could respond to, aspire to, or even become the privileged classes. The toggle between the tramp and suave gave Raj Kapoor more freedom to establish his star-communication with the masses. He evoked pity and his endearing innocence rendered purity to his marginalized image. His humour in difficulty gave him a dignity and his helplessness with the ways of modernity gave him the distance that a star needs to assert himself as someone from outside the system, but wishes to re-work on it with noble intentions. Nandy tells us that Kapoor's negotiation with the city in popular cinema uses "too narrow a range of psychological shades" which is turned into an "over-used proforma cliché". This itself allowed actor-director Kapoor to preside over India's mythic world in the 1950s. His persona was "built around an ambivalent celebration of the city as street culture". "Turning the streets of Bombay into a friendly village neighbourhood", Kapoor reconciles his "moral and aesthetic unease with the city" and pays a "tribute to a remembered village" (2001: 26).

In Deewar (1975), the angry young man of the docks rebels and enters the world of crime on an invitation. The star-quotient that determines Amitabh's body language as against his peers remains intact through 
his move from the "unintended city" to the official city (Nandy, 1998: 2). However, the "unintendedness itself, that faced its biggest crisis during the 70s" (Mazumdar, 2007: 6), becomes the underlying strength of the starsubtext of the angry young man phenomenon that Bachchan ruled the industry with. He established himself as the "first urban-industrial man in Indian popular cinema, one who made the earlier chocolate-pie heroes obsolete" (Nandy, 2001: 26). His persona split from Raj Kapoor's Nehruvian idealism and located itself in the despair of his times. It manifested itself in his restraint, economy of expression and brooding, inward-looking gaze rendered the migrant labour of the dockyard a sharp threat, a potential to erupt any moment. Symptomatic of its time, Bachchan gave on-screen presence to the otherwise meek outsider who would take it no more. He legitimized the illegitimate and illegal, asserted the individuality of the forever wronged (Karna), but could not redeem himself of moral culpability. To that extent, Bachchan fought two wars, one with the outside world and the other with himself. This inner conflict reflected "the course of India's ambivalent relationship with the urban industrial vision" (Nandy, 2001: 21). Deewar catapulted Bachchan to absolute stardom. His threatening persona as a dock labourer as well as his success as a smuggler stood as the ultimate proof of the failure of Nehruvian state. Bombay brought back the mythical space of Mahabharat but with the modern individual star standing in for Karna, the metropolis could not redeem itself.

Satya (1998), however, brought to our attention the non-star individual walking out of the mythical space into the labyrinthine city of Bombay, haunted by its own past and in a perpetual struggle to reconcile with its own diverse cinematic representations. In the absence of the star figure, the protagonist has no parallel communication with the viewer. Instead, as the narrative progresses, the garbage heaps and other crevices of urban dream of Bombay expose themselves. The "residual city" (Mazumdar, 2007: 151) as opposed to the official city articulates a subaltern personality of the city itself. While the tapori figure provided a counterpoint to the mainstream star, this residual city rendered an alternative star persona to the official images of Bombay city. Not only was the residual city further explored, underlined, addressed by the gangster films that followed Satya, it acquired a star status of its own. When the protagonist of Satya enters Bombay through VT station without any past whatsoever or even a memory-trap to be invoked repeatedly, his journey through the Bombay underworld narrates a "politics of urban space" (151), one of the many stories of Bombay city itself. The cinematic past of the city as against its everyday banality, the subaltern excesses, the need for speed, impossibility of finding privacy and the contemporary social topography of the city - all these elements constitute the aura of Bombay. Gangster films render the highest order of thrill to mere survival in Bombay which is indeed threatened.

The old thematic of friction between individual and his society, or the inner conflict of the star protagonist, no longer carries the moral appeal of the pre-gangster cinema. Bombay itself becomes the star figure. The difficult city fractures all communitarian ideas and isolates every individual. While stripping all its inhabitants of the very possibility of the aura of stardom, the metropolis becomes the lone star. Its crisis ridden past overwrites the memory of its inhabitants while its spatial confusion between the wastelands and high-rises overwrites the moral confusion of its dwellers. Bombay establishes a parallel dialogue with the audience through the haunting presence of construction sites and abandoned textile factories. This spatial dialogue between the viewer and the viewed city earlier happened only through the well-known iconography of the metropolis - Gateway of India, Taj Hotel, Marine Drive, Juhu beach etc. In Satya, we see none of that old iconography, instead the new spatial vocabulary includes the dingy suburbs and their dilapidated, abandoned, and puddle streets.

Therefore, the fatigue caused by the rise and fall of the Nehruvian dream precipitates the cinematic urban cityscape into two fragments: a huge wasteland constituting the gangster genre, and a congregation of the giant private spaces marked by "panoramic interiors" (Mazumdar, 2007: 110) feeding into a diasporic cinema. The star figure then, disturbed by the "aesthetic of garbage" (173), relegates himself to the panoramic interior. He is - Shah Rukh Khan, in most cases - uncomfortable within the supremely haunting presence of Bombay. Gangster cinema, 
therefore, works at a fair distance from the star system and the aura of Bombay's enigmatic persona can only be co-habited by the non-star individual.

However, the emergence of a star figure usually marks a moment in cinema as well as the society. The text of stardom, therefore, leads us into a historical question just as the aura around the star on screen is composed of his on-screen as well as off-screen past. A very important trope for our study, then, would be the use of flashback in melodramatic mode that invokes the past so as to suit the unity of a selective narrative trajectory cutting out on other subjective narratives.

\section{Flashback in Melodrama: Memory and the Past}

Flashback is a popular device that manipulates the hermeneutic code of cinematic narrative. Melodrama, on the other hand, exhibits "hyperbolic tendencies and knotty narrative coincidences...evil forces necessitated suspenseful last minute rescues or noble sacrifices in films which provided directly stated moral lessons and pursued elaborately wrought and obviously underscored symbolism" (Turim, 1989: 39). Flashbacks contribute to this hyperbole by heightening characters' emotional states. They help feed the plot by allowing the reconstitution of an enigmatic past which may still bear upon the present. This is why, flashbacks have had a steady presence in Indian Cinema, often considered primarily melodramatic cinema.

The presence of the star figure can also be seen working in harmony with flashbacks. As it is often used in Indian cinema, the character-based flashbacks tell us a privileged version of the story. Not only does it lift the aura of the star and his version of how the crisis was staged and how he reconciled with it or responded to it, but it also weaves the spectators into a certain emotional trajectory - accentuated in melodramatic mode by the hyperbolic tendencies - that essentially connects them deeply to the protagonist. The flashback images "distort spatio-temporal relations and transform visual codes of representation to indicate the thought patterns, the feelings, and even the functioning of the psyches of the characters" (Turim, 1989: 69).

Awara and Deewar, both melodramatic films, invoke the past, to establish genealogy of crime and traumatic memory respectively, in order to rationalize the moment and therefore, determine the further trajectory. In Awara, Raju's memory leads us through the flashback that lasts almost as long as the film while in Deewar, it is the mother (Nirupa Roy) whose memory takes us back in time to visit what was "hidden from public view", the "unofficial history" that imbues Vijay's tragedy with a "secrecy, a subterranean quality" (Prasad, 1998: 148). Evidently, as the mother stands at the heart of the conflict between two brothers who stand for two opposed ideologies, her flashback sets the two brothers up against each other. Had the story been told from Vijay's perspective, it might have had much less to do with the brother Ravi and much more with the mother. Both the films, therefore, create "both the present and the past, which inserts itself in the present, as a series of highly personal experiences" (Turim, 1989: 122-3). Nowhere is it more evident than in the scene under the bridge where the two brothers meet at the height of their conflict. As the school prayer is sung by schoolchildren in the background, haunting the moment with childhood imagery, Vijay reminds Ravi of the importance of the location. He invokes the childhood they spent together under the bridge to establish their togetherness in the metropolis. But the language of memory has no space in Ravi's objective vision. If Vijay is forever exiled, Ravi is the man of the moment. Deewar sets the past and present against each other, except that the past in Deewar is never devoid of a present-ness. The remark engraved on Vijay's arm - Mera baap chor hai [My father is a thief] - is a marker of the same. 
As a film narrative is marked not only by the "presence of a given flashback but the absence of others, not only on what information is presented in a flashback, but what is left out" (1989: 43), flashbacks' heightening of emotions by invoking melodramatic memory is essentially individualistic. In Satya, the non-star protagonist doesn't fit the star-expectations that flashbacks are burdened with in Indian films. Satya, the protagonist, is free of any moral dilemma. He is neither settling score against his past nor builds a dialogue with it. He walks into Bombay through Victoria Terminus without providing us any glimpse into his past and leaving the spectators "free to imagine any of a range of possible flashbacks, available from previous films" (Prasad, 2004: 91). While in Awara, Raju, in a particularly important scene, sells his medal of 'honesty' before setting out to the criminal ways, Vijay in Deewar, true to his 'angry young man' image, takes the risk of life several times to launch himself. Satya's entry into the world of crime is much more straightforward. He doesn't abandon any world, neither moral nor his existential self; he takes to crime and sticks to it in order to survive, no more no less. The film too, provides no moral justification for his entry into the world of crime. The crisis is completely externalized; the inner conflict finds no expression. The story of Satya is told rather matter-of-factly when compared to the memory trapped narratives of Deewar and Awara. It takes no interest in "the sociology of criminal behaviour" that Deewar concerned itself with. Satya, like most gangster films, retains "an existential relationship to the characters; their location within the city is neither causally nor sociologically explained" (Mazumdar, 2007: 212).

The city of Satya is a complex labyrinthine space. Though highly stylized in its portrayal it maintains an understated articulation of its self-identity, which comes across as much more nuanced than elsewhere. It is "a site of ruin, from within which a range of discourses can emerge" (2007: 3). It cannot be unentangled into a simple duality between the rich and successful multi-millionaires as against street urchins [Awara] or between the objective and subjective relationship to the city space [Deewar]. It is inhabited by despair, darkness and violence, an architectural unity that is marked by incomplete projects, omnipresent threat to life and garbage heaps. It provides no time or space for idealism or an inner conflict, both necessary in some capacity for a melodramatic narrative. As the film itself articulates, in gangster business, he who strikes first wins. The compulsion to out-think the other and make the first strike not only marks the crime world, but also the violence of urban spaces outside the world of crime. The meaning, relevance and the very idea of family, in such a scenario, changes significantly.

\section{Decline of Biological Family}

Two factors are very important to comprehend the moment of relative disappearance of biological family in Indian films: first, the changing pattern of migration into the city and second, the rise of diasporic joint family as the repository of traditional values, heavy duty consumerism and celebration of last-name specific togetherness.

Post-globalization, the nature as well as the order of migration to metropolitan cities was radically changing. While earlier, such displacement was neither desired nor practiced among middle classes, the lucrative salaries and an eruption of white-collar job openings in certain cities brought hordes of educated middle class professionals out of their small-town comforts and relatively laid back lives. The migrant labour was not the only one migrating now. But more importantly, migrating to the metropolis often meant a dream come true. The nostalgia for the hometown and love for the family were both on a decline. The family, traditionally a source of personal strength, was losing its significance. Very few migrated to the city with their parents, mainly because they could not afford it early into their professional careers. Most of them shared accommodation with friends or colleagues, worked for a few years, then got married and settled into the city. In this atmosphere, urban spaces were filling themselves with young working populations who found only among friends, the togetherness which one earlier found within family. 
At the same time, familial love was aggrandizing itself in its scale. Very little of the joint family existed in reality but the cinematic version of diasporic joint family, found a cause to celebrate the luxury unavailable to anyone in reality. It found its consumers - urban middle-classes mostly - spread across the length and breadth of the country who rode the aspirational charge of tidal waves caused by globalization. The cinema of Karan Johar and Yash Chopra "spectacularized" (Mazumdar, 2007: 138) this very family by making it a repository of traditional family values, religious customs, cultured human bonds and what I call 'last-name specific togetherness'. The family albums grew dramatic not only in cinema but in real life too. Those who could afford it would now live the ' $\mathrm{K} 3 \mathrm{G}^{2}$ life' as long as they could.

The split in the very notion of family manifested itself in two very different kinds of cinemas. One celebrated the family, its traditions and its heavy duty consumerism whereas the other used its reductive nuclear form only to make a marginal case for personal loss. If the family was nearly mythical (drawing upon Ramayana, the epic) in Awara, too sacred in Deewar to be harmed for the gain of criminal community, the very desire for familial pleasure in Satya becomes an immoral luxury in the face of forever threatened collective survival. Deewar, however, was extraordinary for its times to have depicted a split between the familial aspiration as well: if the mother and brother form the legitimate biological family, the pregnant girlfriend is the illegitimate one. But Satya, the protagonist in Satya, has no biological family. His aspiration for a peaceful life, then, depends on his innocent girlfriend who ensures his death instead. Yet, his death does not put him to eternal sleep which Vijay finds in his mother's arms. Satya's tragic death seeking his lover's embrace, as opposed to Vijay's finding peace in death, demonstrates the changing meaning of familial aspirations. In post-globalization Bombay, not even love comes to rescue the protagonist of his moral culpability.

Yet, friends do come to the rescue. In the absence of family, gangster cinema brings to the fore, the gangfamily itself. The city of gangster films has "re-emerged as the location of a homelessness forever trying to reconcile non-communitarian individualism and associated forms of freedom with communitarian responsibilities, freely borne. Apparently, the city of the mind does not fear homelessness; it even celebrates homelessness" (Nandy, 2001: 19). This celebration brings together the members of the gang, with Kallu Mama as its father figure. They form a residual family within the residual city. Every member of this family is an ordinary individual, not a star figure, but an individual nonetheless, a potential protagonist of an untold story from within Satya.

To elaborate on this, we must place Goli maar bheje mein [Shoot a bullet through my brain, Satya, 1998] against Bole Chudiyan [Bangles speak, Kabhi Khushi Kabhi Gham, 2001] and notice how the two songs communicate the idea of family. If the latter is a multi-starrer, former is a non-starrer. Evidently, part of the starappeal is communicated by fulfillment of desire which is expressed in the latter by pairing two stars of opposite sex together. As against that, gangsters of Satya have no access to women, permanent housing and livelihood options, surely not for any delicate emotions. The song in Satya, with its "druken disposition, sense of irreverence, and conversational lyrics, projects a world of male friendship and bonding" (Mazumdar, 2007: 180). The song in $\mathrm{K} 3 \mathrm{G}$, with its expensive designer apparels and jewellery, constant invocation of traditional values and delicate refined emotions establish the joint family, palatial bungalow and spouse as the ultimate repository of happiness and fulfillment, celebrate love and fertility in a lavish yet ritualistic manner. A significant idea articulated within the film is presentation of parents as an image of the Gods. To further elaborate on the point, contrast 'Apni maang suhaagan ho sang hamesha saajan ho/ Aake meri duniya mein waapas na jaana' [May I always be wedded, May I always have my love with me/ Don't desert me once you've come into my life, Kabhi Khushi Kabhi Gham, 2001] with 'Din mein kholi raat teen batti pe guzaar di/ Thodi chadh gayi toh teen patti mein utaar di' [Spent the day in the Kholi and the night at the traffic signal/ When got slightly tipsy, played cards all along, Satya, 1998] to see how the films that celebrate the family locate their primary concerns around the issues of love, longing, 
consummation and marriage. Gangster cinema, on the other hand, articulates issues of livelihood, difficulty of accessing basic infrastructure in urban spaces and eventually, ends up celebrating homelessness with alcohol and cards - sub-cultural motifs of a life lived on the edge of organized spaces,

The gangster cinema, therefore, is marked by a loss of the delicate familial emotions and it celebrates its crude, vulgar and raw deprivation. It celebrates homelessness, anger, darkness and violence to articulate the subaltern excesses in opposition to the post-globalization mainstream consumerism which lies completely beyond its reach. It is this deprivation in Satya that substantiates the void left by the omission of an outside moral framework, isolating the individual with his desire and longing for a normal life, thus asserting his "pathological" (Prasad, 2004: 91) condition in the city of Bombay. The isolated individual now becomes his own moral axis; in the absence of the faintest memory of the village or a past, his family cannot determine his behaviour, bring him back into the fold, or force a crisis upon him.

However, perhaps we need to credit Ramgopal Varma with pioneering an independent model of gangster cinema. After all, the aesthetic model he deployed in Satya cannot entirely be explained by the temporal sociocultural context of Bombay and Bombay cinema. It had a distinct mark of Varma's cinematic language earlier expressed in his debut feature Shiva (1989), the first Indian film to use 'steadycam' for the chase sequences (Mazumdar, 2007: 229). The understated yet chilling representation of urban violence and economy of expression sharpened by an evocative mise-en-scene that we witness in Shiva, has a lot in common with Satya as well. Also, Varma's conscious relative distance from star figures and excessive use of spatial imagery to communicate with his audience is not as much a marker of any linear progression in cinematic history as a deliberate intervention. To see this more clearly, it may help to study, as a counterpoint, Vaastav (1999), a film that closely followed the success of Satya, was received very well at the box-office, also addressed the gangsters' world, but could not have been more different in its cinematic language and dramatic assertions. Vaastav is closer to Deewar than to Satya. The haunting presence of the mother figure in Dutt's life is indicative of that. Also, the outside moral framework, consciously removed from Satya is omnipresent in Vaastav. The film is popular cinema's response to Satya, and is a distinctly melodramatic star film. ${ }^{3}$

Therefore, Satya, and Ramgopal Varma in particular, renders to the gangster, a cinematic identity that is in sync with his times and his condition within the urban space. Neither Vaastav, nor Parinda (1989), both films that use star-power, operate within melodramatic stylistics and lean too heavily on the idea of childhood ${ }^{4}$ could produce a sustainable aesthetic model of the gangster figure. This is exactly why the success of Satya, and Varma too, is rather unique for Satya provides us with a prototype of the gangster that breaks away from the tradition of Awara and Deewar, gets rid of the tropes that assert on stardom and epic-scale proportions more than the immediate and ordinary - space that is inhabited and questions of survival - in order to offer us an aesthetic register that was, and perhaps is still, yet to realize its true valency. That is why we must try to comprehend the fundamental appeal, the 'elementary morality' of this gangster figure.

The gangster is beyond the reformist nationalist possibility of the 1950s or the mere disenchantment of the 1970s. He, despite acting in his existential interest, remains loyal only to his brethren, those who share his pathological condition of urban delirium. Therefore, he has risen above the personal, the familial and the private. He is forever exiled, locked out in Bombay, loyal only to a higher, more impersonal morality. Indeed, no wonder then that his personal investments in his girlfriend are punished by the narrative. Though we feel sympathy for his condition, we also acknowledge his pathological flaw which remains unattended by his unforgiving middle-class girlfriend who disapproves of all sociological possibilities of the gangster figure. Satya's relatively disembodied loyalty is to his condition itself, neither to an objective nor subjective reality. Ontology and genealogy both are unable to rationalize this pathological condition. Therefore, the gangster figure in particular - and gangster cinema 
in general - by foregrounding the pathological, leads us to an invisible, even formless, institution omnipresent in the urban space. Evidently, the pathological condition renders the motifs of family and memory useless. Thus, it offers us a sharp critique of the dark and lonely world the gangster inhabits. In his death, he leaves us an unfulfilled desire to lead even an ordinary life in Bombay. Perhaps it wouldn't be inappropriate to consider how Albert Camus tried to diagnose the human situation in a world of shattered beliefs:

...in a universe that is suddenly deprived of illusions and of light, man feels a stranger. His is an irremediable exile, because he is deprived of memories of a lost homeland as much as he lacks the hope of a promised land to come. This divorce between man and his life, the actor and his setting, truly constitutes the feeling of Absurdity. (Camus, 1942: 18)

\section{References}

Camus, A. (1942). The Myth of Sisyphus. Paris: Gallimard.

Chatterjee, G. (1993). Awara. New Delhi: Wiley Eastern.

Mazumdar, R. (2007). Bombay Cinema: An Archive of the City. Minneapolis \& London: University of Minnesota Press.

Miller, T. (2000). Stars and Performance. In Stam R. \& Miller, T. (Eds.), Film and Theory: An Anthology. Massachusetts, USA \& Oxford, UK: Blackwell Publishers.

Mukerjee, H. (1964). The Gentle Colossus: A Study of Jawaharlal Nehru. New Delhi: Oxford University Press.

Nandy, A. (1998). Indian Popular Cinema as a Slum's Eye View of Politics. In Ashis N. (Eds.), The Secret Politics of Our Desires: Innocence, Culpability, and Indian Popular Cinema. New Delhi: Oxford University Press.

(2001). The Ambiguous Journey to the City: The Village and Other Odd Ruins of the Self in Indian Imagination. New Delhi: Oxford University Press.

Prasad, M. (1998). Ideology of the Hindi Film: A Historical Construction. New Delhi: Oxford University Press.

(2004). Realism \& Fantasy in Representations of Metropolitan Life in Indian Cinema. In City Flicks: Indian Cinema and the Urban Experience. Calcutta, New Delhi: Seagull Books.

Turim, M. (1989). Flashbacks. In Film: Memory \& History. New York \& London: Routledge. 
1 The idea and the features of panoramic interiors are further explored in 'Decline of Biological Family' subsection.

2 Referring to Kabhi Khushi Kabhi Gham (2001), an immensely popular film by Karan Johar, celebrating the family as the repository of all virtue.

3 Though Vaastav (1999) is reasonably concerned about the world of gangsters, its true concerns lie in the protagonist's eventual moral closure and offering a potential sociology of crime world, a trope markedly absent in Satya. The Mother, who eventually kills her gangster son, reminds us of Mother India while Dutt's death in her lap takes us back to Deewar. Vaastav is neither marked by understatement of any kind - on the contrary, it is rather loud - nor is able to establish the horror of urban delirium. However, the experience of the residual city experienced by the gangster, foregrounded by Satya, became central in the works of later filmmakers.

${ }^{4}$ The childhood is invoked either through flashbacks, as in Parinda, or through the positioning of the mother figure, as in Vaastav, who maps the present onto the past, the adult over the child.

Akshaya Kumar is doing his Master of Arts at the School of Arts and Aesthetics in Jawaharlal Nehru University, New Delhi. His interests include Cultural Studies, Memory Studies, Cinema Studies, Theatre and Performance Studies. His recent work investigates the changing urban matrix of Indian towns, big or small, and the class/ sex/ age based negotiations repositioning new communities, reworking their desires and reconfiguring their embodied selfhood and their performative identities, within the spatial politics of urban culture. 